\title{
ResearchOnline@JCU
}

This is the author-created version of the following work:

Tebbett, Sterling B., Goatley, Christopher H.R., and Bellwood, David R. (2018)

Algal turf sediments across the Great Barrier Reef: putting coastal reefs in perspective. Marine Pollution Bulletin, 137 pp. 518-525.

Access to this file is available from:

https://researchonline.jcu.edu.au/56875/

(C) 2018 Elsevier Ltd. All rights reserved.

Please refer to the original source for the final version of this work: 


\section{Algal turf sediments across the Great Barrier Reef: putting coastal reefs in perspective}

\section{Authors:}

Sterling B. Tebbett ${ }^{1}$, Christopher H.R. Goatley ${ }^{2}$, David R. Bellwood ${ }^{1}$

\section{Addresses:}

${ }^{1}$ ARC Centre of Excellence for Coral Reef Studies; and College of Science and Engineering, James Cook University, Townsville, Queensland 4811, Australia

${ }^{2}$ Function, Evolution and Anatomy Research Lab and Palaeoscience Research Centre, School of Environmental and Rural Science, University of New England, Armidale, New South Wales 2351, Australia

*Corresponding Author:

Email: sterling.tebbett@my.jcu.edu.au

Phone: (07) 47815729

\section{Keywords:}

Continental Shelf; Coral Reef; Detritus; Epilithic Algal Matrix; Terrestrial Sediments; Turbidity 


\begin{abstract}
Sediments trapped within algal turfs play a key role in mediating ecosystem processes on reefs. Despite this ecological importance, our understanding of turf-bound sediments on coastal reefs is limited, even though such reefs are heavily exposed to terrestrial sediments. We compared algal turf sediment loads, composition and grain size distributions among coastal reefs along the Great Barrier Reef (GBR) and compared these to turf-bound sediments on reefs across the GBR. Algal turf sediment loads on coastal reefs were on average 9.4 times higher than offshore reefs (range 2.2-16.1 times). Among coastal reefs there was marked variability in the loads $\left(797.87-3681.78 \mathrm{~g} \mathrm{~m}^{-2}\right)$, composition (organics 1.0-8.9\%; silicates 27.4-93.0\%) and grain size of sediments. Our data highlight the potential variability in physical and ecological factors that control sediment dynamics on coastal reefs, including proximity to rivers, and reveal that turfs on coastal reefs are heavily influenced by sediments.
\end{abstract}

\title{
Introduction
}

Sediments are ubiquitous components of all coral reefs, yet increased sediment inputs are widely regarded as one of the foremost stressors faced by coral reefs (Arias-González et al., 2017; Burke et al., 2011; Fabricius, 2005). Indeed, more than 50\% of all reefs, are considered to be at risk of sediment-mediated degradation (Burke et al., 2011). The reefs at risk generally occur close to shore, where exposure to land-based sources of sediment is maximised (Burke et al., 2011; Fabricius et al., 2014; Wolanski et al., 2008). Even on Australia's Great Barrier Reef (GBR), it has been suggested that sediment inputs have increased 500\% since European settlement (Kroon et al., 2012; McCulloch et al., 2003). However, the extent that sediment inputs have increased, and the nature of the relationship between increased inputs and sediment supply to nearby coral reefs, remains an actively debated subject (Larcombe and Woolfe, 1999; Lewis et al., 2016; Orpin and Ridd, 2012).

On coral reefs, increased sediment inputs can arise from changes to agricultural practices, coastal development and nearshore dredging activities (Brodie and Pearson, 2016; Fisher et al., 2018; McCook et al., 2015; Suchley and Alvarez-filip, 2018). The terrestrial inputs tend to be composed of 
fine, siliceous material, often associated with organic material in 'flocs' which are readily transported in river plumes or via resuspension (Bainbridge et al., 2012; Orpin and Ridd, 2012; Wolanski et al., 2008). These siliceous sediments differ markedly from the coarser, biogenic carbonate sediments found on most reefs (Gordon et al., 2016a; Tebbett et al., 2017a). High sediment loads, particularly of fine siliceous material, have an array of deleterious effects on numerous marine organisms (Erftemeijer et al., 2012; Fabricius, 2005; Storlazzi et al., 2015; Tebbett et al., 2017b), potentially putting the long-term persistence of affected coral reefs in jeopardy.

Despite the risks sediments pose to coral reefs, high coral cover can occur in sediment-rich localities (Browne et al., 2012; DeVantier et al., 2006). For instance, there are many small coral reefs in the nearshore region of the GBR which show relatively rapid growth even in the face of high turbidity levels (Perry et al., 2013, 2012). However, our understanding of sediment dynamics in these systems is centred around sediments suspended in the water column, changes in light availability, and the process of sedimentation (i.e. where sediments fall out of suspension and settle onto the corals themselves) (e.g. Browne et al., 2013a, 2013b; Whinney et al., 2017). While suspended sediments and sedimentation are undoubtedly important, and may influence the structure and function of coral reefs (Jones et al., 2015; Mallela and Perry, 2007; Moustaka et al., 2018; Woolfe and Larcombe, 1999), these processes are temporally variable (Browne et al., 2013b; Whinney et al., 2017) and provide only a partial picture of sediment dynamics on reefs. Even on turbid coastal reefs, the greatest proportion of sediment mass is likely to be trapped on the benthos within turfs, i.e. the epilithic algal matrix (EAM), which has received relatively little attention, especially on mainland-attached coastal reefs.

The EAM is often the dominant benthic cover on coral reefs (Goatley and Bellwood, 2011; Jouffray et al., 2014; Smith et al., 2016; Vermeij et al., 2010). Composed of algal turfs, sediment, detritus, microalgae, microbes and cryptofauna, the EAM (sensu Wilson et al., 2003) represents a critical interface between the water column and the reef, and mediates critical ecological processes including coral settlement (Arnold et al., 2010; Birrell et al., 2005), herbivory (Adam et al., 2018; Choat et al., 2002) and primary productivity (Bellwood et al., 2018; Hatcher, 1988). Increasingly, evidence is suggesting that such key ecosystem processes are mediated by the amount of sediment 
within the EAM (herein, this is considered the sediment load, however it has been referred to under a number of terms previously, including accumulated sediments, deposited sediments and benthic sediments) (Bellwood et al., 2018; Fong et al., 2018; Goatley et al., 2016; Ricardo et al., 2017; Tebbett et al., 2017c). Unfortunately, these EAM sediments appear temporally stable and, once accumulated on the benthos these sediments may represent a chronic, long-term stressor (Gordon et al., 2016a; Tebbett et al., 2018).

Evidently, the EAM is a core component of coral reefs. However, to date, the sediment loads within the EAMs of coastal reefs (herein considered mainland-attached fringing reefs) have not been quantified, nor compared to other reefs on the GBR. On the GBR there are distinct gradients in sediment properties across the shelf, due to differing proximities to rivers and physical oceanographic conditions (Fabricius et al., 2014; Larcombe and Carter, 2004; Tebbett et al., 2017a). As the coastal reefs are likely to be some of the most heavily affected by terrestrial sediment inputs and other anthropogenic stressors, an understanding of EAM sediments on these reefs is vital. The aim of this study, therefore, is to compare and contrast EAM sediments among coastal fringing reefs across 500 $\mathrm{km}$ of the North Queensland coast. To provide insights into how coastal EAM sediments compare to EAM sediments on reefs further offshore, we will also compare the mass and grain size distribution of coastal reef EAM sediments with representative samples from reefs across the GBR.

\section{Materials and Methods}

\section{Study Sites}

EAM sediment samples were collected on coastal reefs (fringing reefs attached to the mainland) along the North Queensland coast from Myall Beach, Cape Tribulation (16 $5^{\circ} 15.81^{\prime \prime} \mathrm{S}$,

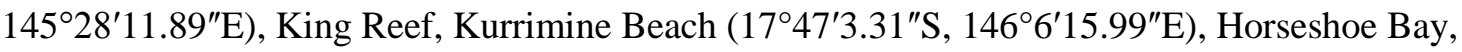
Bowen $\left(19^{\circ} 58^{\prime} 45.52^{\prime \prime} \mathrm{S}, 148^{\circ} 15^{\prime} 40.23^{\prime \prime} \mathrm{E}\right)$ and Hydeaway Bay, Cape Gloucester (20 $4^{\prime} 17.59^{\prime \prime} \mathrm{S}$, $148^{\circ} 28^{\prime} 59.63^{\prime \prime} \mathrm{E}$ ) between December 2014 and July 2015 (Fig. 1). Sites were primarily chosen to cover a broad stretch of the North Queensland coast, as well as based on their accessibility and reduced risk of natural hazards (primarily crocodiles). At each site, the reef was directly accessible 
from the mainland, with sampling generally being undertaken on the lowest astronomic tides which allowed reef walking out to the reef 'crest', except at Bowen where sampling was undertaken on SCUBA (in $1-2 \mathrm{~m}$ of water). It should be noted that as sampling was conducted at low spring tides, water movement had the potential to alter loads through increased resuspension and removal, or deposition. However, to date, evidence has highlighted that EAM sediment loads are temporally stable at both short (days) (Tebbett et al., 2018) and long (months) (Gordon et al., 2016a) scales, suggesting that any effects would have been limited. On these coastal reefs the 'crest' is marked by a narrow area where the reef flat transitions into deeper water. The reef crest was chosen because it is generally the most dynamic zone in regards to reef processes, and also exhibits the lowest sediment loads across reef depth gradients (Goatley and Bellwood, 2012; Gordon et al., 2016a; Purcell, 2000). Reefs were generally of low topographic complexity and predominantly covered by sediment-laden turfing algae and macroalgae (e.g. Sargassum sp., Halimeda sp., Padina sp.). Scleractinian coral cover varied across the reefs but in all cases the coral communities were dominated by sediment tolerant taxa (e.g. Coelastrea sp., Porites sp.) (Done, 1982). While sampling on SCUBA at Bowen, we observed the EAM being grazed by the parrotfish, Scarus rivulatus, and the rabbitfish, Siganus doliatus. These species are among the few nominally herbivorous fishes common on inshore reefs of the GBR (Cheal et al., 2012; Johansson et al., 2013). 


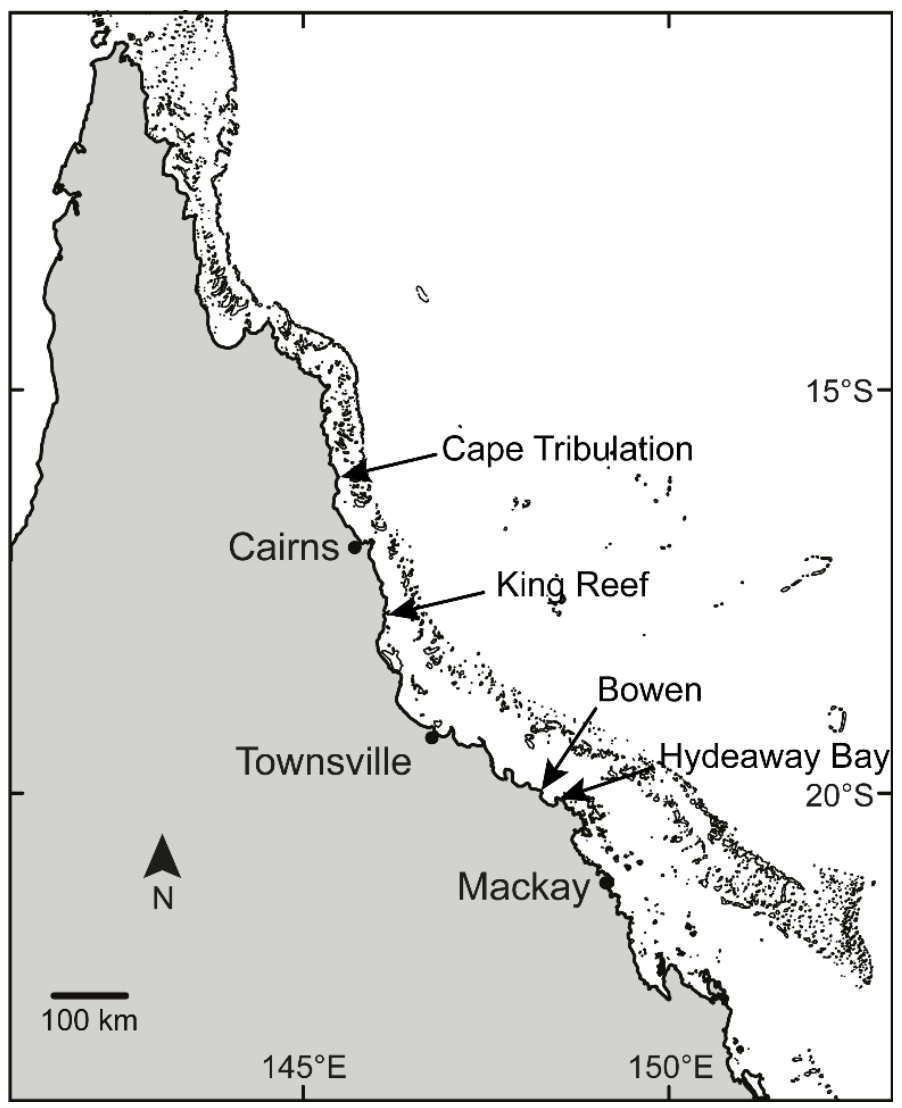

Figure 1 Map showing the four coastal reefs along the Great Barrier Reef from which sediments within the epilithic algal matrix were sampled.

\section{Sediment sampling}

EAM sediment sampling was undertaken by vacuuming particulate material (inorganic sediments and associated organic material) from within a $58 \mathrm{~cm}^{2} \mathrm{PVC}$ ring placed on a suitable EAMcovered surface using a submersible electronic vacuum sampler (Purcell, 1996). In this study suitable EAM-covered surfaces were considered hard reef matrix that was flat, free of large sediment-retaining pits, macroalgae and encrusting organisms following Purcell, (2000). This sampling protocol ensured sediment was relatively homogenous over the sampling area, i.e. not accumulated within pockets. EAMs of this nature were abundant at all sampling sites and care was taken to ensure consistency of surface selection at all sites, especially the angle of the surface which can impact sediment accumulation (Duran et al., 2018). The extent of coverage by turfing algae was not used in the 
selection of sampling areas because algae was often masked/covered by high sediment loads. Nine samples were collected from each site.

\section{Sediment processing}

Initially, $16 \mathrm{ml}$ of $4 \%$ buffered formaldehyde was added to the samples to fix organic material. Each of the samples was then transferred to a 91 container and left for 3 hours to allow particulate material $>10 \mu \mathrm{m}$ to settle before decanting the water (Purcell, 1996). All samples were transferred to $120 \mathrm{ml}$ samples jars then wet sieved through a $2 \mathrm{~mm}$ stainless steel mesh, retaining only particulate material $<2 \mathrm{~mm}$ (sands, silts and clays; ISO 14688-1:200). Each sample was then vigorously agitated and allowed to settle for 24 hours (to ensure a consistent settling period) before the depth of particulates in the $120 \mathrm{ml}$ sample jars was recorded. Depth measurements were taken because particulate volume and mass (as measured below) are not necessarily related and can be affected by properties of the particulates such as particle size and composition (see Gordon et al., 2016a). The depth of particulates was measured in three haphazard locations around the jar. Measurements were standardised by the sampling area to give the relative depth of particulate loads within the EAM on the reefs.

Following depth measurements, each sample was rinsed three times with fresh water, to remove salts, leaving a minimum 3 hour settling period between rinses. The samples were then dried to a constant weight at $60^{\circ} \mathrm{C}$ and weighed to yield total benthic particulate mass. To remove organic material, samples were bleached for at least two weeks using $30 \%$ hydrogen peroxide $\left(\mathrm{H}_{2} \mathrm{O}_{2}\right)$ or $10 \%$ sodium hypochlorite solution $\left(\mathrm{NaHClO}_{4}\right)$ following Purcell, (1996). The method used depended on the solution available at the time. In both cases, fresh solutions were added regularly. After bleaching with $\mathrm{NaHClO}_{4}$, samples were rinsed with fresh water after reactions had stopped. Samples were then re-dried and weighed, as above, to yield inorganic sediment mass, organic mass, and percentage of organics in benthic particulates. Bleached, dried samples were then fractioned by particle size using a sieve stack $(1000,500,250,125$, and $63 \mu \mathrm{m})$. The size fractions were then individually weighed. Finally, to determine the loads of terrestrially-derived silicates in the inorganic sediments, samples 
were treated with $5 \%$ hydrochloric acid $(\mathrm{HCl})$ for a minimum of three days and until no bubbles were produced in $24 \mathrm{~h}$, to remove carbonates (following Gordon et al., 2016a). Samples were then rinsed three times with fresh water to remove salts, dried and weighed as above yielding siliceous sediment mass.

\section{Statistical analysis}

The depths of the benthic particulates were examined using a linear mixed effects model. A mixed effects model was necessary to allow sample ID to be fitted as a random factor, accounting for the repeated measures of depth from the same samples. The benthic particulate mass, organic mass, inorganic sediment mass, and siliceous sediment mass were compared among coastal reefs using generalised linear models (GLMs) fitted with a Gamma distribution. The proportion of organics in total benthic particulates, and the proportion of inorganic sediment mass composed of siliceous sediments were compared among coastal reefs using beta regression models. In all models, reef (Hydeaway Bay, Bowen, King Reef, Cape Tribulation) was fitted as a fixed effect. Model fits were assessed using residual plots, all of which were satisfactory. Tukey HSD multiple comparisons of means were used post-hoc to compare among-factor levels in the GLMs. Statistical analyses were performed in the statistical software R (R Core Team, 2017), using the multcomp (Hothorn et al., 2008), betareg (Cribari-Neto and Zeileis, 2010) and nlme (Pinheiro et al., 2017) packages.

Grain size distribution patterns were initially inspected using a non-metric multidimensional scaling (nMDS) ordination based on a Euclidean distance matrix of standardised data. Differences among reefs were examined using a permutational multivariate analysis of variance (PERMANOVA). Following the PERMANOVA, pair-wise tests were performed to determine where between reef differences occurred. The assumption of homogeneity of dispersions for the PERMANOVA was tested using permutational analysis of multivariate dispersions (PERMDISP). A canonical analysis of principle components (CAP) was employed following the PERMANOVA to visualise significant groupings. Multivariate analysis was performed using PRIMER 7.0 PERMANOVA+. 
Comparison with EAM sediments across the GBR

The total load and grain size distribution of inorganic EAM sediments from the coastal fringing reefs were then compared to other EAM sediment samples from the GBR. EAM sediment samples from the reef crest of the inner-shelf reefs (Turtle Group North, Turtle Group South, Orpheus Island, Magnetic Island), mid-shelf reefs (Lizard Island, North Direction Island) and outer-shelf reefs (Day Reef, Yonge Reef) were compared to coastal reefs. For data from Magnetic Island eight sediment samples were collected from the EAM on the reef crest in Nelly Bay $\left(19^{\circ} 10^{\prime} 17.41^{\prime \prime} \mathrm{S}\right.$, $146^{\circ} 50^{\prime} 52.09^{\prime \prime}$ ) (ESM Fig. S1) on SCUBA and processed as above to yield total inorganic sediment load and grain size distributions. All other data from the GBR were sourced from Goatley et al., (2016) and Tebbett et al., (2017a).

To compare the total inorganic mass among shelf locations, a GLMM with a Gamma distribution was used. In this case, shelf position was treated as a fixed effect and individual reef was treated as a random effect. The model fit was assessed using residual plots as above. Tukey HSD multiple comparisons of means were used post-hoc to compare among-effect levels of the GLMM. Statistical analyses were performed using the multcomp (Hothorn et al., 2008) and lme4 (Bates et al., 2015) packages in $R$ ( $R$ Core Team, 2017). Grain size distribution patterns were examined among shelf positions, as for coastal reefs, using PRIMER 7.0 PERMANOVA+. However, in this case the PERMANOVA design included shelf-position as a fixed factor and individual reef as a random factor.

\section{Results}

Coastal reef sediments

The mass of benthic particulates in the EAM on the coastal reefs ranged from 836.11 to $3717.44 \mathrm{~g} \mathrm{~m}^{-2}$. The two northern reefs (Cape Tribulation and King Reef) had significantly higher particulate loads than the two southern reefs (Bowen and Hydeaway Bay), with a three-fold difference in average loads (Fig. 2a; ESM Table S1, S2). By contrast, there was little variation in the depth of 
benthic particulate material among coastal reefs, with mean depths ( \pm SE) varying from $2.93 \pm 0.16$ $\mathrm{mm}$ at Hydeaway Bay, to $3.68 \pm 0.4 \mathrm{~mm}$ at King Reef (Fig. 2b); no significant differences were detected among individual reefs (ESM Table S1, S2). Average inorganic sediment loads ranged from $\left(797.87-3681.78 \mathrm{~g} \mathrm{~m}^{-2}\right)$ and followed the same patterns among reefs as seen for total benthic particulate loads (Fig. 2c; ESM Table S1, S2).

The quantity of siliceous sediments also varied markedly among the reefs. The two northern reefs had significantly higher loads of siliceous sediments than the two southern reefs, with average loads of $2174.23 \pm 502.99$ and $3430.51 \pm 666.49 \mathrm{~g} \mathrm{~m}^{-2}$ for Cape Tribulation and King Reef, respectively (ESM Tables S1, S2). These high loads of siliceous sediments accounted for $83.25 \pm 3.12$ and $92.95 \pm 0.47 \%$ of the total inorganic sediment mass in the EAM on Cape Tribulation and King Reef, respectively (Fig. 2d, ESM Table S1, S3). Surprisingly, siliceous sediments only accounted for $38.65 \pm 1.23$ and $27.42 \pm 1.59 \%$ of the total inorganic sediment mass in the EAM at Bowen and Hydeaway Bay, respectively (Fig. 2d, ESM Table S1, S3).

The distribution of organic particulates differed substantially from the patterns seen in both particulate loads, inorganic sediment loads and for siliceous sediments. Despite yielding some of the lowest overall sediment loads, the EAMs at Bowen contained, on average, $2.62-2.87$ fold greater masses of organic material than the other coastal reefs (Fig. 2e). The percentage of organic particulates (relative to total particulate mass) followed a similar trend: ( \pm SE) $8.86 \pm 1.94 \%$ at Bowen, compared to $4.58 \pm 0.48 \%$ at Hydeaway Bay, $1.03 \pm 0.1 \%$ at King Reef and $1.65 \pm 0.27 \%$ at Cape Tribulation (Fig. 2f). For both the organic load and percentage of organics in the benthic particulates the levels at Bowen were significantly higher than all other reefs (ESM Table S1, S3). 

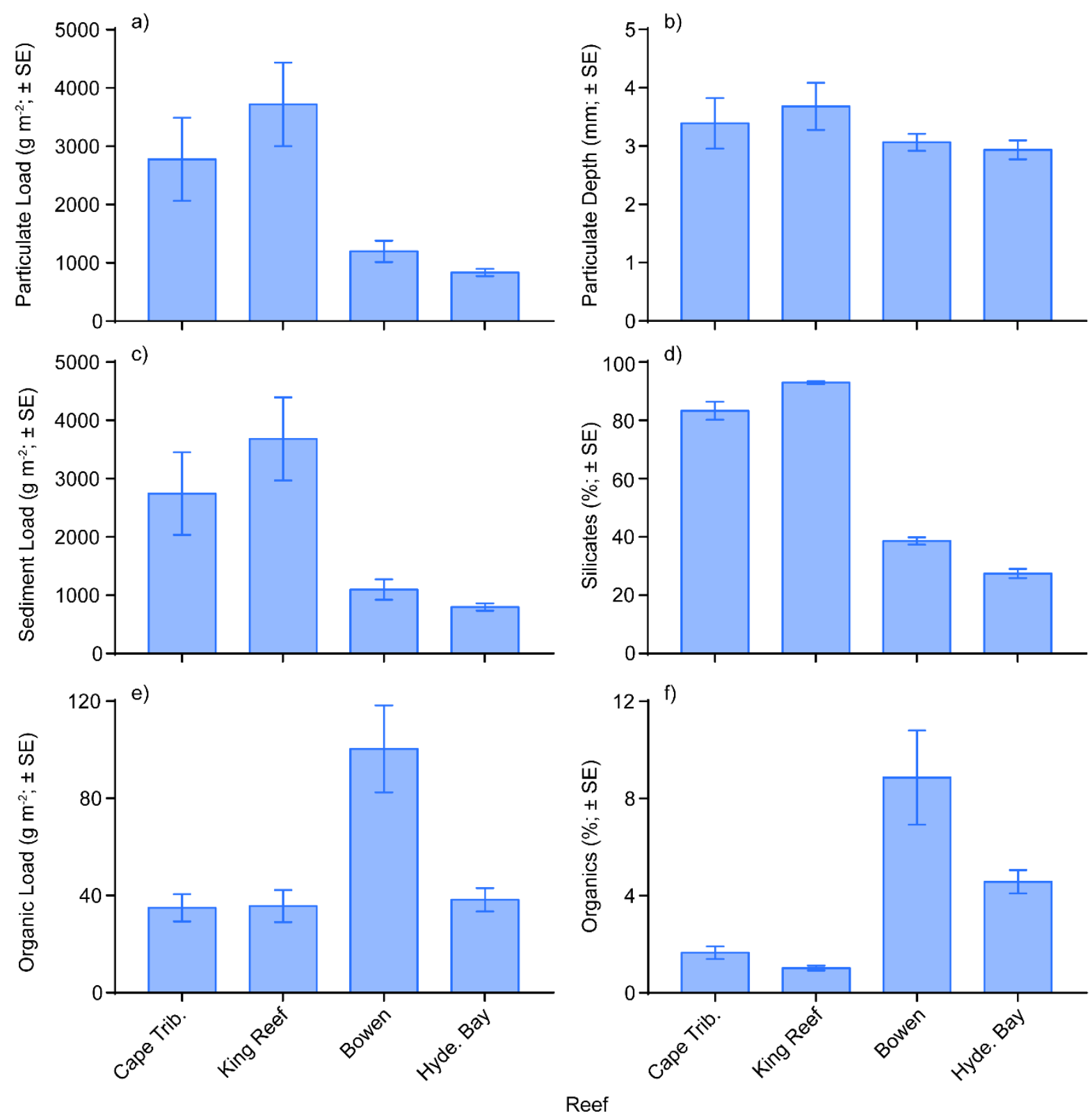

Figure 2 The mean a) benthic particulate mass, b) benthic particulate depth, c) inorganic sediment mass, d) percent of inorganic sediments composed of silicates, e) organic particulate mass and f) percent of organic material in benthic particulates from the epilithic algal matrix on four coastal reefs on the Great Barrier Reef. Trib. = Tribulation, Hyde. = Hydeaway Bay.

Significant differences in the sediment grain-size distributions were detected among individual reefs (PERMANOVA: Pseudo- $\mathrm{F}_{3,30}=28.016, p_{\text {[perm] }}<0.001$ ). Pairwise comparisons indicated that all reefs were different from one another, apart from Hydeaway Bay and Bowen (Fig. 3; 
ESM Table S4). Generally, separation was driven by a particular grain-size which dominated in sediments on an individual reef (e.g. the prevalence of very fine sand (63 - $125 \mu \mathrm{m}$; ISO 14688 1:200) in the EAM sediments at Cape Tribulation and medium sand $(250-500 \mu \mathrm{m}$; ISO 14688 1:200) in the EAM sediments at King Reef; Fig. 3; Table S3). The PERMDISP $\left(\mathrm{F}_{3,27}=1.615, p_{[\mathrm{perm}]}=\right.$ 0.34) identified no differences in data dispersion among the samples.

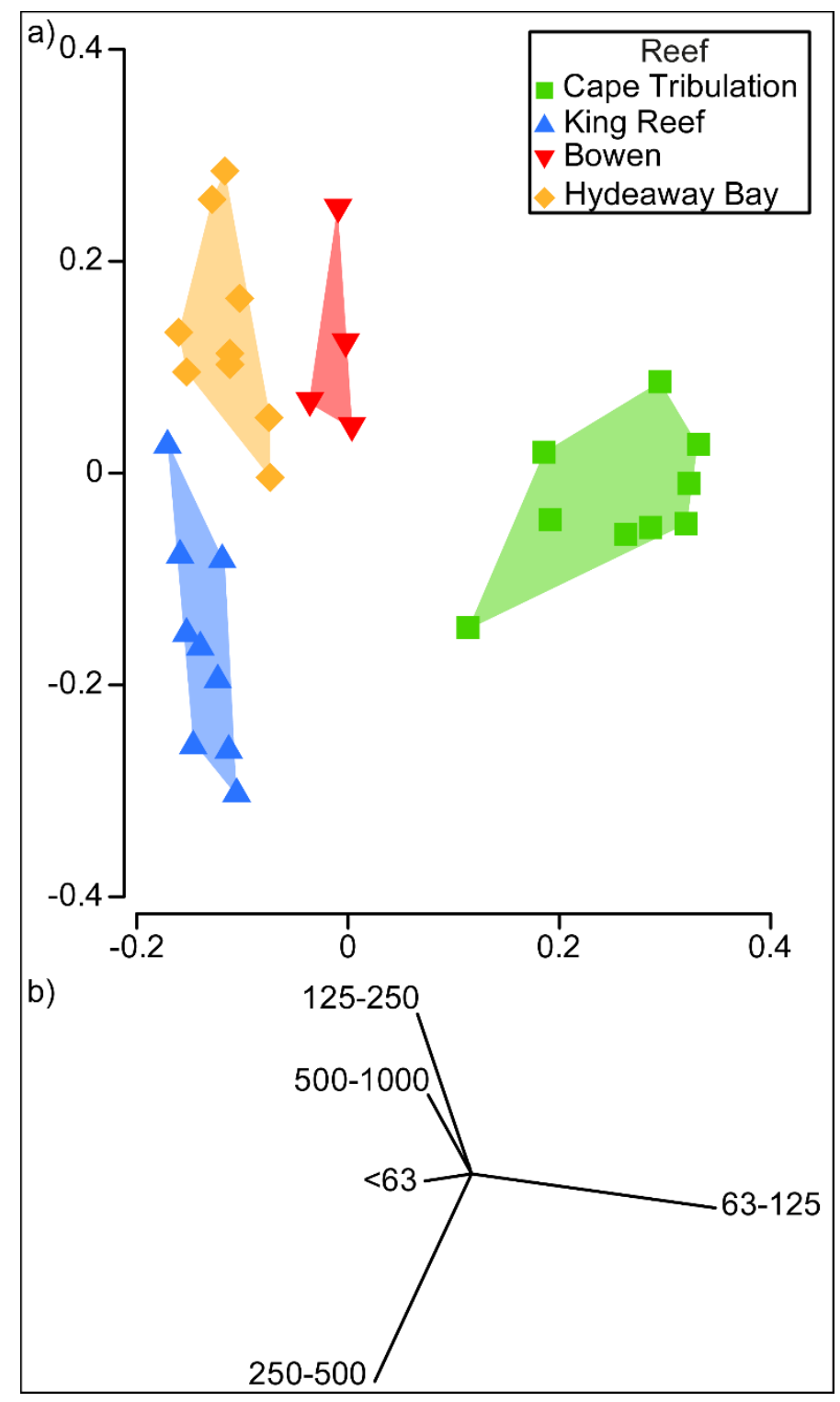

Figure 3 a) Canonical analysis of principal (CAP) coordinates ordination based on a Euclidean distance matrix of standardised grain size distribution data $(0-2000 \mu \mathrm{m})$ from sediments contained within the epilithic algal matrix on four coastal reefs along the Great Barrier Reef. b) Vectors show the relationship among sediment grain size fractions $(\mu \mathrm{m})$ and how they influence the position of data 
points in the CAP. Vectors were calculated using a multiple correlation model. The $1000-2000 \mu \mathrm{m}$ vector did not contribute substantially to the observed patterns and is not shown. Coloured polygons are to aid visual interpretation and do not denote significant groupings (Bowen and Hydeaway Bay do not differ significantly).

\section{Coastal reef sediments in a cross-shelf context}

The mass of sediments contained within the EAM on coastal reefs was an order of magnitude higher than mid- and outer-shelf reefs. Indeed, the average sediment load on coastal reefs $(2169.07 \pm$ $\left.339 \mathrm{~g} \mathrm{~m}^{-2}\right)$ was more than twice as high as that on inner-shelf reefs $\left(1004.65 \pm 118.07 \mathrm{~g} \mathrm{~m}^{-2}\right)$, more than sixteen times as high as mid-shelf reefs $\left(134.84 \pm 31.13 \mathrm{~g} \mathrm{~m}^{-2}\right)$ and nearly ten times as high as outer-shelf reefs $\left(219.61 \pm 52.38 \mathrm{~g} \mathrm{~m}^{-2}\right.$ (Fig. 4). Sediment loads on coastal reefs differed significantly from those on the mid- and outer-shelfs (ESM Table S5, S6). Although inner-shelf reef sediment loads were not found to be significantly different from coastal reefs, they were also significantly higher than mid- and outer-shelf reefs (ESM Table S5, S6).

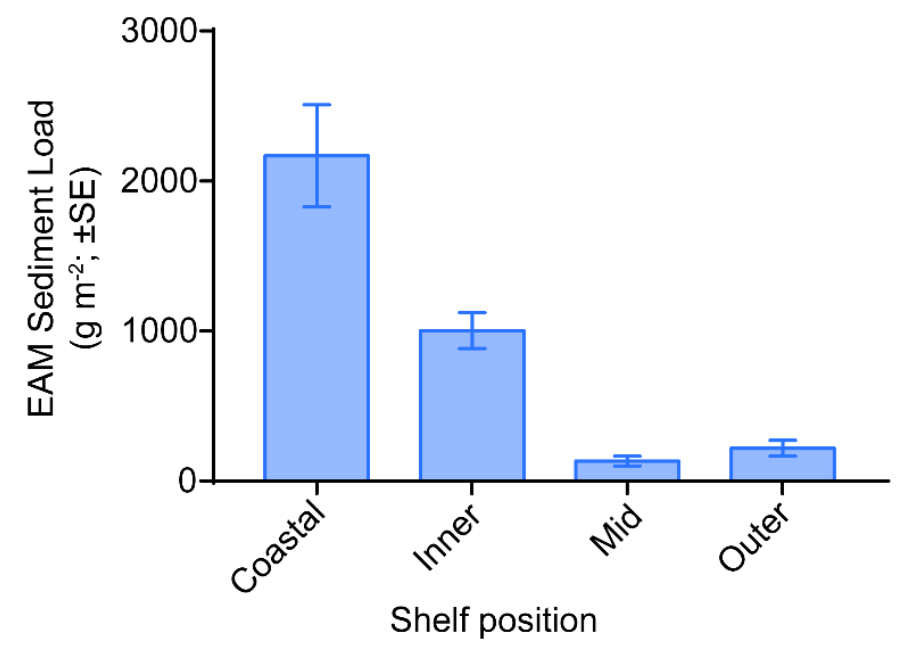

Figure 4 Sediment loads within the epilithic algal matrix (EAM) across the Great Barrier Reef. All samples were from reef crest habitats ( $n=33$ [coastal], 38 [inner], 17 [mid], 20 [outer]).

In general, coastal reefs appeared to accumulate fine and very fine sands $(63-250 \mu \mathrm{m}$; ISO 14688-1:200), especially when compared to outer-shelf reefs which appeared to accumulate coarse and very coarse sands $>500 \mu \mathrm{m}$ (Fig. 5). Surprisingly, while mid-shelf reefs had the lowest overall 
sediment loads (Fig. 4), they also had the highest relative levels of silts and clays in the finest sediment size fraction $(<63 \mu \mathrm{m})$. However, despite some clear clustering in the data (Fig. 5), the PERMANOVA suggested that shelf-positions were not grouped by their grain-size distributions (PERMANOVA: Pseudo- $\left.\mathrm{F}_{3,105}=1.503, p_{[\mathrm{perm}]}=0.1836\right)$. While groupings were not significant, the PERMDISP revealed that there were significant differences in the diversity of grain size distributions (dispersion) among shelf positions (PERMDISP: $\mathrm{F}_{3,102}=3.4412, p_{[\text {perm] }}<0.05$ ). Pairwise comparisons revealed that these differences occurred between inner- and outer-shelf reefs $\left(t=2.6544, p_{\text {[perm] }}<\right.$ $0.05)$.

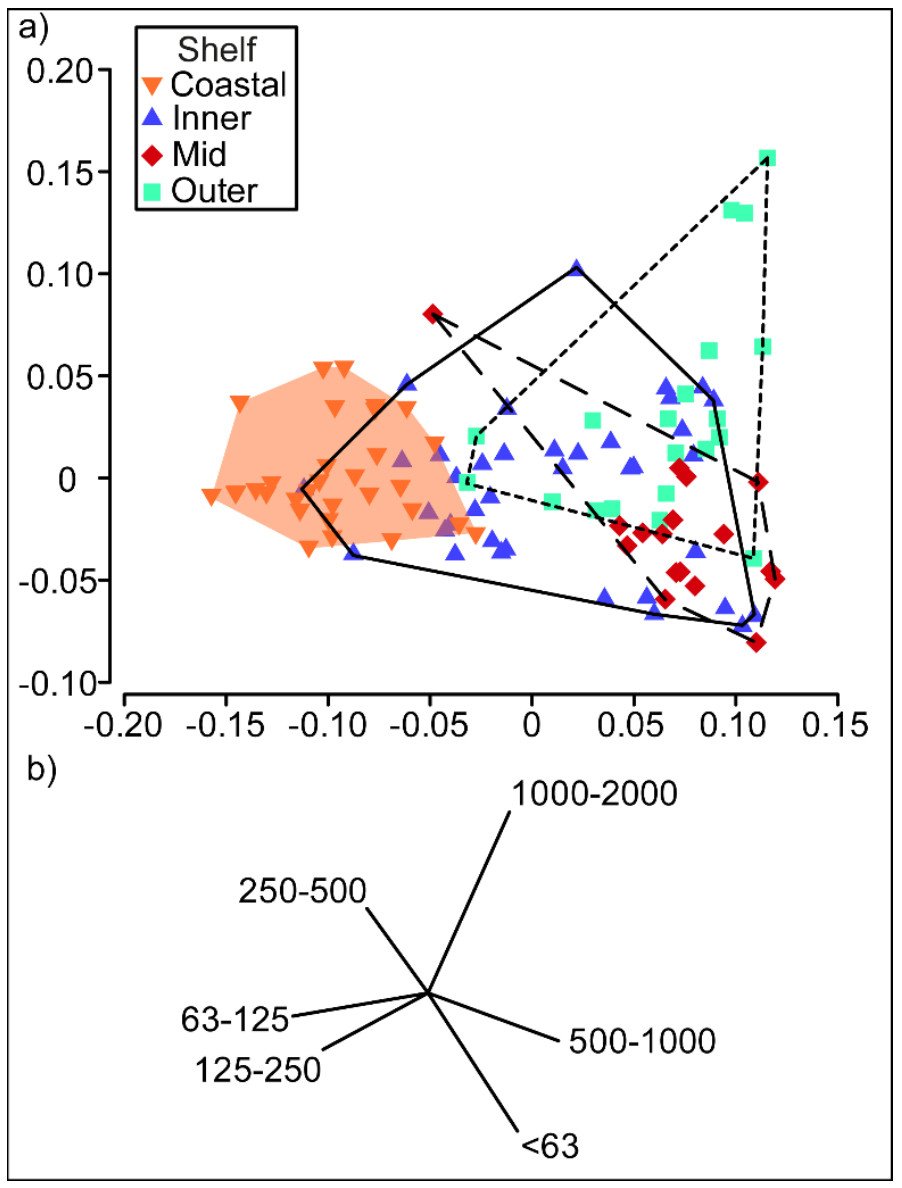

Figure 5 a) Canonical analysis of principal (CAP) coordinates ordination based on a Euclidean distance matrix of standardised grain size distribution data $(0-2000 \mu \mathrm{m})$ from sediments contained within the epilithic algal matrix on reef crests across the Great Barrier Reef. b) Vectors show the relationship among sediment grain size fractions $(\mu \mathrm{m})$ and how they influence the position of data 
points in the CAP. Vectors were calculated using a multiple correlation model. Polygons are to aid visual interpretation and do not denote significant groupings.

\section{Discussion}

Our findings revealed that EAM sediment loads on coastal reefs are significantly higher, and generally composed of more $63-250 \mu \mathrm{m}$ size sediments, than those located further offshore. As EAM-bound sediments are a major driver underpinning key reef processes on coral reefs (Adam et al., 2018; Birrell et al., 2005; Clausing et al., 2014; Fong et al., 2018; Rodríguez-Martínez et al., 2011) these high sediment loads are likely to have distinct consequences for the ecological processes operating on coastal reefs. Furthermore, we revealed that the EAM sediments on coastal reefs are not spatially consistent, but instead displayed marked variability in terms of total loads ( $797.87-3681.78$ $\mathrm{g} \mathrm{m}^{-2}$ ), composition (silicate content: $27-93 \%$ ) and grain size distributions among individual reefs. The variability of EAM sediments on these reefs is likely to be underpinned by the local sediment inputs, physical conditions and ecological processes acting at each reef; all affect sediment dynamics (Browne et al., 2013a; Kench and Brander, 2006; Ogston et al., 2004; Pomeroy et al., 2018; Tebbett et al., 2017a).

The largest differences in sediment profiles among the coastal reefs, was between the two northern (Cape Tribulation and King Reef) and the two southern reefs (Bowen and Hydeaway Bay). The reefs at Bowen and Hydeaway Bay had relatively low sediment loads and similar grain size distributions, suggesting they experience a similar suite of environmental influences. This may arise as a result of the position of both reefs, on peninsulas, making them more exposed to currents and other hydrodynamic activity (Wolanski, 1994). This may reduce the amount of sediment that can settle onto the benthos or increase resuspension. By contrast, King Reef and Cape Tribulation were not located on peninsulas and were also the two least topographically complex reefs, with similar morphologies that did not reach substantial heights above the off-reef sediment apron (Pers. Obs. SBT). As such, these reefs (King Reef and Cape Tribulation) may be particularly prone to the effects 
of sediment deposition (Ogston et al., 2004; Orpin and Ridd, 2012), offering substantial potential for sediment trapping in the EAM (Carpenter and Williams, 1993; Kendrick, 1991). The dominance of siliceous sediments in the EAM of the two northern reefs is particularly noteworthy. This highlights the potential importance of 'new' sediments delivered via flood plumes and terrestrial run-off, or resuspension of previously deposited siliceous sediments from the off-reef sediment apron, on these reefs (Fabricius et al., 2013; Lewis et al., 2014; Orpin and Ridd, 2012). Alternatively the wave action on the southern reefs may decrease the levels of both fine and siliceous sediments in the EAM through the cleaning effects of resuspension.

Organic particulate loads were also variable among coastal reefs and were far lower than those previously reported from mid-shelf reef crests (Lizard Island) (Purcell and Bellwood, 2001). In particular, the proportion of organic material at King Reef and Cape Tribulation were especially low at 1.03 and $1.65 \%$, respectively (Fig. 2), compared to $14 \%$ reported from Lizard Island (Purcell and Bellwood, 2001). Organic particulates are generally referred to as detritus on reefs, and represent a key nutritional resource for many nominally herbivorous fishes (Choat et al., 2002; Kelly et al., 2016; Tebbett et al., 2017d). It has been suggested that high sediment levels reduce feeding by nominally herbivorous fishes on the EAM by 'watering down' the nutritional value of detritus via an increased ratio of inorganic particulates (Gordon et al., 2016b; Purcell and Bellwood, 2001; Tebbett et al., 2017c). As the two northern reefs had the highest sediment loads, this process of diluting the nutritional value of the EAM detrital loads may be occurring on these reefs.

When considered alongside the other shelf positions, the exceptionally high sediment loads on the coastal reefs is clearly apparent. These high loads, on average 13 times higher than mid- and outer-shelf reefs, may be the combined result of; a) proximity to the mainland, b) limited hydrodynamic activity, c) reef geomorphology and/or d) a depauperate fish community. Each will be considered in turn. (a) On nearshore reefs terrestrial siliceous sediments can make up a large proportion of total inorganic sediment mass (Fig. 2d), with the contribution of terrestrial sediment inputs decreasing substantially across the continental shelf (Fabricius et al., 2014; Larcombe and Carter, 2004; Tebbett et al., 2017a). (b) The relative strength of hydrodynamic activity, which can be 
responsible for removing sediments from the EAM, decreases across the shelf from the Coral Sea towards the coast (Bellwood and Wainwright, 2001; Crossman et al., 2001). (c) Coastal reefs occur in shallower water and often their height above the sediment apron is minimal relative to reefs further offshore (Done, 1982; Larcombe and Carter, 2004), making them particularly prone to the effects of sediment resuspension from the off-reef sediment apron (Orpin and Ridd, 2012; Wolanski et al., 2008). Finally, (d) these coastal reefs probably lack the abundance and diversity of fishes which remove sediments from, and maintain low sediment loads in, the EAM (Cheal et al., 2012; Goatley and Bellwood, 2010; Johansson et al., 2013). In summary, these coastal reefs can experience heavy sediment inundation from terrestrial sources and local resuspension, and once this sediment is trapped within the EAM they lack the substantial wave energy or 'sediment removing' fishes that could redistribute this sediment. High sediment loads are inevitable.

The high sediment loads within the EAM of coastal and, to a lesser extent, inner-shelf reefs, as well as their potential to be inundated by periodic sediment pulses, carry a number of ecological consequences in terms of the functioning of these systems. Of all benthic processes that appear to be affected by EAM sediments (e.g. Adam et al., 2018; Clausing et al., 2014; Eurich et al., 2018; Jones et al., 2015), perhaps the most ecologically relevant are the effects of sediment on the growth and nature of the algal turfs themselves. Indeed, the sediment loads appeared to be so high on coastal reefs that the algal turfs were overwhelmed by sediment. These observations are supported by recent experimental studies which have demonstrated the negative effects of sediment loading on the development and productivity of algal turfs (Clausing et al., 2014; Tebbett et al., 2018). Indeed, a sediment load comparable to that seen on coastal reefs reduced the amount of algal turf productivity consumed by herbivorous fishes by over $2000 \%$ (Tebbett et al., 2018). As algal turfs are generally the single largest contributor to primary productivity on reefs (Carpenter, 1985; Hatcher, 1988), if algal turf development is suppressed by sediments then benthic productivity on these coastal reefs is likely to be limited, with bottom-up effects on associated food chains. As such, these sediment-rich nearshore systems are likely to function in markedly different ways to ecosystems on mid- and outershelf reefs. 
It should be noted that as the coastal reefs examined herein, differ markedly in their structure and function to reefs further offshore, the cross-shelf comparison of EAM sediment loads is somewhat inconsistent. However, even though coastal reefs are quite distinct, the cross-shelf comparison is necessary to put the findings from coastal reefs in context with other reef systems, i.e. highlighting that they are sediment-rich reef systems. Furthermore, while this study provides a baseline for future work, and amalgamates our understanding of EAM sediment loads across the GBR, it relied on relatively coarse sediment characterisation techniques to allow data to be directly compared and contrasted with previous studies. Future work on coastal reef sediments could be extended using more advanced techniques such as laser diffraction particle size analysis, and nitrogen fractionation (e.g. Judy et al., 2018; Weber et al., 2006), which are likely to provide new insights into the nature and dynamics of EAM sediments on reefs.

Unfortunately, to-date, despite the mounting evidence that EAM sediments affect key reef processes (see Adam et al., 2018; Clausing et al., 2014; Fong et al., 2018; Ricardo et al., 2017; Tebbett et al., 2017c), we have little understanding of the mechanistic link between suspended sediments, sedimentation and the EAM. The largest focus, especially on turbid nearshore reefs, has been on suspended sediment dynamics (e.g. Browne et al., 2013b; Fabricius et al., 2014; Orpin and Ridd, 2012; Pomeroy et al., 2018), with more recent work linking suspended sediments to sedimentation (Whinney et al., 2017). EAM sediments are rarely considered, yet they appear to make up a large component of sediments on reefs, and are likely to underpin many ecological patterns that have been correlated with turbidity (Bejarano and Appeldoorn, 2013; Cheal et al., 2013; Fabricius et al., 2005; Moustaka et al., 2018). The extent to which sediments dominate both coastal and inner-shelf reefs highlights the potential ecological importance of sediments in structuring the functioning of these systems. 


\section{Acknowledgements}

We thank J. Khan for field assistance; F. Latrille for assistance with sample processing; and one anonymous reviewer for insightful comments. This work was supported by the Australian Research Council (DRB: grant number CE140100020).

\section{Competing Interests Statement}

On behalf of all authors, the corresponding author states that there are no competing interests. 


\section{References}

Adam, T.C., Duran, A., Fuchs, C.E., Roycroft, M.V., Rojas, M.C., Ruttenberg, B.I., Burkepile, D.E., 2018. Comparative analysis of foraging behavior and bite mechanics reveals complex functional diversity among Caribbean parrotfishes. Mar Ecol Prog Ser 597, 207-220. doi:https://doi.org/10.3354/meps 12600

Arias-González, J.E., Fung, T., Seymour, R.M., Garza-Pérez, J.R., Acosta-González, G., Bozec, Y.M., Johnson, C.R., 2017. A coral-algal phase shift in Mesoamerica not driven by changes in herbivorous fish abundance. PLoS One 12, e0174855. doi:10.1371/journal.pone.0174855

Arnold, S.N., Steneck, R.S., Mumby, P.J., 2010. Running the gauntlet: inhibitory effects of algal turfs on the processes of coral recruitment. Mar Ecol Prog Ser 414, 91-105. doi:10.3354/meps08724

Bainbridge, Z.T., Wolanski, E., Álvarez-Romero, J.G., Lewis, S.E., Brodie, J.E., 2012. Fine sediment and nutrient dynamics related to particle size and floc formation in a Burdekin River flood plume, Australia. Mar Pollut Bull 65, 236-248. doi:10.1016/j.marpolbul.2012.01.043

Bates, D., Maechler, M., Bolker, B., Walker, S., 2015. Fitting linear-mixed effects models using lme4. J Stat Softw 67, 1-48.

Bejarano, I., Appeldoorn, R., 2013. Seawater turbidity and fish communities on coral reefs of Puerto Rico. Mar Ecol Prog Ser 474, 217-226. doi:10.3354/meps10051

Bellwood, D.R., Tebbett, S.B., Bellwood, O., Mihalitsis, M., Morais, R.A., Streit, R.P., Fulton, C.J., 2018. The role of the reef flat in coral reef trophodynamics: Past, present, and future. Ecol Evol 8, 4108-4119. doi:10.1002/ece3.3967

Bellwood, D.R., Wainwright, P.C., 2001. Locomotion in labrid fishes: implications for habitat use and cross-shelf biogeography on the Great Barrier Reef. Coral Reefs 20, 139-150. doi:10.1007/s003380100156

Birrell, C.L., McCook, L.J., Willis, B.L., 2005. Effects of algal turfs and sediment on coral settlement. Mar Pollut Bull 51, 408-414. doi:10.1016/j.marpolbul.2004.10.022

Brodie, J.E., Pearson, R.G., 2016. Ecosystem health of the Great Barrier Reef: time for effective management action based on evidence. Estuar Coast Shelf Sci 183, 438-451. doi:10.1016/j.ecss.2016.05.008

Browne, N.K., Smithers, S.G., Perry, C.T., 2013a. Carbonate and terrigenous sediment budgets for two inshore turbid reefs on the central Great Barrier Reef. Mar Geol 346, 101-123. doi:10.1016/j.margeo.2013.08.011

Browne, N.K., Smithers, S.G., Perry, C.T., 2013b. Spatial and temporal variations in turbidity on two inshore turbid reefs on the Great Barrier Reef, Australia. Coral Reefs 32, 195-210. doi: 10.1007/s00338-012-0965-1

Browne, N.K., Smithers, S.G., Perry, C.T., 2012. Coral reefs of the turbid inner-shelf of the Great Barrier Reef, Australia: An environmental and geomorphic perspective on their occurrence, composition and growth. Earth-Science Rev 115, 1-20. doi:10.1016/j.earscirev.2012.06.006

Burke, L., Reytar, K., Spalding, M., Perry, A., 2011. Reefs at Risk Revisited. World Resources Institute, Washington, DC, USA.

Carpenter, R.C., 1985. Relationships between primary production and irradiance in coral reef algal communities. Limnol Oceanogr 30, 784-793. doi:10.4319/lo.1985.30.4.0784 
Carpenter, R.C., Williams, S.L., 1993. Effects of algal turf canopy height and microscale substratum topography on profiles of flow speed in a coral forereef environment. Limnol Oceanogr 38, 687694. doi:10.4319/lo.1993.38.3.0687

Cheal, A.J., Emslie, M., MacNeil, M.A., Miller, I., Sweatman, H., 2013. Spatial variation in the functional characteristics of herbivorous fish communities and the resilience of coral reefs. Ecol Appl 23, 174-188. doi:10.1890/11-2253.1

Cheal, A.J., Emslie, M., Miller, I., Sweatman, H., 2012. The distribution of herbivorous fishes on the Great Barrier Reef. Mar Biol 159, 1143-1154. doi:10.1007/s00227-012-1893-x

Choat, J.H., Clements, K.D., Robbins, W.D., 2002. The trophic status of herbivorous fishes on coral reefs 1: dietary analyses. Mar Biol 140, 613-623. doi:10.1007/s00227-001-0715-3

Clausing, R.J., Annunziata, C., Baker, G., Lee, C., Bittick, S.J., Fong, P., 2014. Effects of sediment depth on algal turf height are mediated by interactions with fish herbivory on a fringing reef. Mar Ecol Prog Ser 517, 121-129. doi:10.3354/meps11029

Cribari-Neto, F., Zeileis, A., 2010. Beta regression in R. J Stat Softw 34, 1-24.

Crossman, D.J., Choat, J.H., Clements, K.D., Hardy, T., McConochie, J., 2001. Detritus as food for grazing fishes on coral reefs. Limnol Oceanogr 46, 1596-1605. doi:10.4319/lo.2001.46.7.1596

DeVantier, L.M., De'ath, G., Turak, E., Done, T.J., Fabricius, K.E., 2006. Species richness and community structure of reef-building corals on the nearshore Great Barrier Reef. Coral Reefs 25, 329-340. doi:10.1007/s00338-006-0115-8

Done, T.J., 1982. Patterns in the distribution of coral communities across the central Great Barrier Reef. Coral Reefs 1, 95-107. doi:10.1007/bf00301691

Duran, A., Collado-Vides, L., Palma, L., Burkepile, D.E., 2018. Interactive effects of herbivory and substrate orientation on algal community dynamics on a coral reef. Mar Biol 165, 156. doi:10.1007/s00227-018-3411-2

Erftemeijer, P.L.A., Riegl, B., Hoeksema, B.W., Todd, P.A., 2012. Environmental impacts of dredging and other sediment disturbances on corals: A review. Mar Pollut Bull 64, 1737-1765. doi:http://dx.doi.org/10.1016/j.marpolbul.2012.05.008

Eurich, J.G., Shomaker, S.M., Mccormick, M.I., Jones, G.P., 2018. Experimental evaluation of the effect of a territorial damselfish on foraging behaviour of roving herbivores on coral reefs. J Exp Mar Bio Ecol 506, 155-162. doi:10.1016/j.jembe.2018.06.009

Fabricius, K.E., 2005. Effects of terrestrial runoff on the ecology of corals and coral reefs: review and synthesis. Mar Pollut Bull 50, 125-146. doi:10.1016/j.marpolbul.2004.11.028

Fabricius, K.E., De'ath, G., Humphrey, C., Zagorskis, I., Schaffelke, B., 2013. Intra-annual variation in turbidity in response to terrestrial runoff on near-shore coral reefs of the Great Barrier Reef. Estuar Coast Shelf Sci 116, 57-65. doi:10.1016/j.ecss.2012.03.010

Fabricius, K.E., De'ath, G., McCook, L., Turak, E., Williams, D.M., 2005. Changes in algal, coral and fish assemblages along water quality gradients on the inshore Great Barrier Reef. Mar Pollut Bull 51, 384-398. doi:http://dx.doi.org/10.1016/j.marpolbul.2004.10.041

Fabricius, K.E., Logan, M., Weeks, S., Brodie, J.E., 2014. The effects of river run-off on water clarity across the central Great Barrier Reef. Mar Pollut Bull 84, 191-200. doi:10.1016/j.marpolbul.2014.05.012

Fisher, R., Walshe, T., Bessell-Browne, P., Jones, R., 2018. Accounting for environmental uncertainty 
in the management of dredging impacts using probabilistic dose-response relationships and thresholds. J Appl Ecol 55, 415-425. doi:10.1111/1365-2664.12936

Fong, C.R., Bittick, S.J., Fong, P., 2018. Simultaneous synergist, antagonistic, and additive interactions between multiple local stressors all degrade algal turf communities on coral reefs. J Ecol 106, 1390-1400. doi:10.1111/1365-2745.12914

Goatley, C.H.R., Bellwood, D.R., 2012. Sediment suppresses herbivory across a coral reef depth gradient. Biol Lett 8, 1016-1018. doi:10.1098/rsbl.2012.0770

Goatley, C.H.R., Bellwood, D.R., 2011. The roles of dimensionality, canopies and complexity in ecosystem monitoring. PLoS One 6, e27307. doi:10.1371/journal.pone.0027307

Goatley, C.H.R., Bellwood, D.R., 2010. Biologically mediated sediment fluxes on coral reefs: sediment removal and off-reef transportation by the surgeonfish Ctenochaetus striatus. Mar Ecol Prog Ser 415, 237-245. doi:10.3354/meps08761

Goatley, C.H.R., Bonaldo, R.M., Fox, R.J., Bellwood, D.R., 2016. Sediments and herbivory as sensitive indicators of coral reef degradation. Ecol Soc 21, 29. doi:10.5751/ES-08334-210129

Gordon, S.E., Goatley, C.H.R., Bellwood, D.R., 2016a. Composition and temporal stability of benthic sediments on inner-shelf coral reefs. Mar Pollut Bull 111, 178-183. doi:10.1016/j.marpolbul.2016.07.013

Gordon, S.E., Goatley, C.H.R., Bellwood, D.R., 2016b. Low-quality sediments deter grazing by the parrotfish Scarus rivulatus on inner-shelf reefs. Coral Reefs 35, 285-291. doi:10.1007/s00338015-1374-Z

Hatcher, B.G., 1988. Coral reef primary productivity: a beggar's banquet. Trends Ecol Evol 3, $106-$ 111.

Hothorn, T., Bretz, F., Westfall, P., 2008. Simultaneous inference in general parametric models. Biometrical J 50, 346-363. doi:10.1002/bimj.200810425

Johansson, C.L., van de Leemput, I.A., Depczynski, M., Hoey, A.S., Bellwood, D.R., 2013. Key herbivores reveal limited functional redundancy on inshore coral reefs. Coral Reefs 32, 963972. doi:10.1007/s00338-013-1044-y

Jones, R., Ricardo, G.F., Negri, A.P., 2015. Effects of sediments on the reproductive cycle of corals. Mar Pollut Bull 100, 13-33. doi:10.1016/j.marpolbul.2015.08.021

Jouffray, J.-B., Nyström, M., Norstrom, A.V, Williams, I.D., Wedding, L.M., Kittinger, J.N., Williams, G.J., 2014. Identifying multiple coral reef regimes and their drivers across the Hawaiian archipelago. Philos Trans R Soc B Biol Sci 370, 20130268. doi:10.1098/rstb.2013.0268

Judy, J.D., Kirby, J.K., Farrell, M., McLaughlin, M.J., Wilkinson, S.N., Bartley, R., Bertsch, P.M., 2018. Colloidal nitrogen is an important and highly-mobile form of nitrogen discharging into the Great Barrier Reef lagoon. Sci Rep 8, 12854. doi:10.1038/s41598-018-31115-z

Kelly, E.L.A., Eynaud, Y., Clements, S.M., Gleason, M., Sparks, R.T., Williams, I.D., Smith, J.E., 2016. Investigating functional redundancy versus complementarity in Hawaiian herbivorous coral reef fishes. Oecologia 182, 1151-1163. doi:10.1007/s00442-016-3724-0

Kench, P.S., Brander, R.W., 2006. Wave processes on coral reef flats: implications for reef geomorphology using Australian case studies. J Coast Res 22, 209-223. doi:10.2112/05A0016.1 
Kendrick, G.A., 1991. Recruitment of coralline crusts and filamentous turf algae in the Galapagos archipelago: effect of simulated scour, erosion and accretion. J Exp Mar Bio Ecol 147, 47-63. doi:10.1016/0022-0981(91)90036-V

Kroon, F.J., Kuhnert, P.M., Henderson, B.L., Wilkinson, S.N., Kinsey-Henderson, A., Abbott, B., Brodie, J.E., Turner, R.D.R., 2012. River loads of suspended solids, nitrogen, phosphorus and herbicides delivered to the Great Barrier Reef lagoon. Mar Pollut Bull 65, 167-81. doi:10.1016/j.marpolbul.2011.10.018

Larcombe, P., Carter, R.M., 2004. Cyclone pumping, sediment partitioning and the development of the Great Barrier Reef shelf system: a review. Quat Sci Rev 23, 107-135. doi:http://dx.doi.org/10.1016/j.quascirev.2003.10.003

Larcombe, P., Woolfe, K.J., 1999. Increased sediment supply to the Great Barrier Reef will not increase sediment accumulation at most coral reefs. Coral Reefs 18, 163-169. doi:10.1007/s003380050174

Lewis, S.E., Lough, J.M., Cantin, N., Matson, E., Kinsley, L., Brodie, J.E., 2016. An examination of the ability of coral geochemical records to reconstruct suspended sediment loads to the Great Barrier Reef lagoon. Report to the National Environmental Science Programme. Reef and Rainforest Research Centre Limited, Cairns.

Lewis, S.E., Olley, J., Furuichi, T., Sharma, A., Burton, J., 2014. Complex sediment deposition history on a wide continental shelf: implications for the calculation of accumulation rates on the Great Barrier Reef. Earth Planet Sci Lett 393, 146-158. doi:10.1016/j.eps1.2014.02.038

Mallela, J., Perry, C.T., 2007. Calcium carbonate budgets for two coral reefs affected by different terrestrial runoff regimes, Rio Bueno, Jamaica. Coral Reefs 26, 129-145. doi:10.1007/s00338006-0169-7

McCook, L.J., Schaffelke, B., Apte, S., Brinkman, R., Brodie, J., Erftemeijer, P., Eyre, B., Hoogerwerf, F., Irvine, I., Jones, R., King, B., Marsh, H., Masini, R., Morton, R., Pitcher, R., Rasheed, M., Sheaves, M., Symonds, A., Warne, M.S., 2015. Synthesis of current knowledge of the biophysical impacts of dredging and disposal on the Great Barrier Reef: report of an independent panel of experts. Great Barrier Reef Marine Park Authority, Townsville, Australia.

McCulloch, M., Fallon, S., Wyndham, T., Hendy, E., Lough, J., Barnes, D., 2003. Coral record of increased sediment flux to the inner Great Barrier Reef since European settlement. Nature 421, 727-730. doi:10.1038/nature01361

Moustaka, M., Langlois, T.J., Mclean, D., Bond, T., Fisher, R., Fearns, P., Dorji, P., Evans, R.D., 2018. The effects of suspended sediment on coral reef fish assemblages and feeding guilds of north-west Australia. Coral Reefs 37, 659-673. doi:10.1007/s00338-018-1690-1

Ogston, A.S., Storlazzi, C.D., Field, M.E., Presto, M.K., 2004. Sediment resuspension and transport patterns on a fringing reef flat, Molokai, Hawaii. Coral Reefs 23, 559-569. doi:10.1007/s00338004-0415-9

Orpin, A.R., Ridd, P.V, 2012. Exposure of inshore corals to suspended sediments due to waveresuspension and river plumes in the central Great Barrier Reef: a reappraisal. Cont Shelf Res 47, 55-67. doi:10.1016/j.csr.2012.06.013

Perry, C.T., Smithers, S.G., Gulliver, P., 2013. Rapid vertical accretion on a "young” shore-detached turbid zone reef: Offshore Paluma Shoals, central Great Barrier Reef, Australia. Coral Reefs 32, 1143-1148. doi:10.1007/s00338-013-1063-8

Perry, C.T., Smithers, S.G., Gulliver, P., Browne, N.K., 2012. Evidence of very rapid reef accretion 
and reef growth under high turbidity and terrigenous sedimentation. Geology 40, 719-722. doi:10.1130/G33261.1

Pinheiro, J., Bates, D., DebRoy, S., Sarkar, D., R Core Team, 2017. nlme: linear and nonlinear mixed effects models. R package version 3.1-131.

Pomeroy, A.W.M., Lowe, R.J., Ghisalberti, M., Winter, G., Storlazzi, C., Cuttler, M., 2018. Spatial variability of sediment transport processes over intratidal and subtidal timescales within a fringing coral reef system. J Geophys Res Earth Surf 123, 1013-1034. doi:10.1002/2017JF004468

Purcell, S.W., 2000. Association of epilithic algae with sediment distribution on a windward reef in the northern Great Barrier Reef, Australia. Bull Mar Sci 66, 199-214.

Purcell, S.W., 1996. A direct method for assessing sediment load in epilithic algal communities. Coral Reefs 15, 211-213. doi:10.1007/BF01787453

Purcell, S.W., Bellwood, D.R., 2001. Spatial patterns of epilithic algal and detrital resources on a windward coral reef. Coral Reefs 20, 117-125. doi:10.1007/s003380100150

R Core Team, 2017. R: A language and environment for statistical computing. R Foundation for Statistical Computing, Vienna, Austria.

Ricardo, G.F., Jones, R.J., Nordborg, M., Negri, A.P., 2017. Settlement patterns of the coral Acropora millepora on sediment-laden surfaces. Sci Total Environ 609, 277-288. doi:10.1016/j.scitotenv.2017.07.153

Rodríguez-Martínez, R.E., Jordán-Garza, A.G., Maldonado, M.A., Blanchon, P., 2011. Controls on coral-ground development along the northern Mesoamerican reef tract. PLoS One 6, e28461. doi:10.1371/journal.pone.0028461

Smith, J.E., Brainard, R., Carter, A., Grillo, S., Edwards, C., Harris, J., Lewis, L., Obura, D., Rohwer, F., Sala, E., Vroom, P.S., Sandin, S., 2016. Re-evaluating the health of coral reef communities: baselines and evidence for human impacts across the central Pacific. Proc R Soc B Biol Sci 283, 20151985. doi:10.1098/rspb.2015.1985

Storlazzi, C.D., Norris, B.K., Rosenberger, K.J., 2015. The influence of grain size, grain color, and suspended-sediment concentration on light attenuation: why fine-grained terrestrial sediment is bad for coral reef ecosystems. Coral Reefs 34, 967-975. doi:10.1007/s00338-015-1268-0

Suchley, A., Alvarez-filip, L., 2018. Local human activities limit marine protection efficacy on Caribbean coral reefs. Conserv Lett 11, e12571. doi:10.1111/conl.12571

Tebbett, S.B., Bellwood, D., Purcell, S.W., 2018. Sediment addition drives declines in algal turf yield to herbivorous coral reef fishes: implications for reefs and reef fisheries. Coral Reefs 37, 929937. doi:10.1007/s00338-018-1718-6

Tebbett, S.B., Goatley, C.H.R., Bellwood, D.R., 2017a. Algal turf sediments and sediment production by parrotfishes across the continental shelf of the northern Great Barrier Reef. PLoS One 12, e0170854. doi:10.1371/journal.pone.0170854

Tebbett, S.B., Goatley, C.H.R., Bellwood, D.R., 2017b. Fine sediments suppress detritivory on coral reefs. Mar Pollut Bull 114, 934-940. doi:10.1016/j.marpolbul.2016.11.016

Tebbett, S.B., Goatley, C.H.R., Bellwood, D.R., 2017c. The effects of algal turf sediments and organic loads on feeding by coral reef surgeonfishes. PLoS One 12, e 0169479.

doi:10.1371/journal.pone.0169479 
Tebbett, S.B., Goatley, C.H.R., Bellwood, D.R., 2017d. Clarifying functional roles: algal removal by the surgeonfishes Ctenochaetus striatus and Acanthurus nigrofuscus on coral reefs. Coral Reefs 36, 803-813. doi:10.1007/s00338-017-1571-z

Vermeij, M.J.A., Dailer, M.L., Walsh, S.M., Donovan, M.K., Smith, C.M., 2010. The effects of trophic interactions and spatial competition on algal community composition on Hawaiian coral reefs. Mar Ecol 31, 291-299. doi:10.1111/j.1439-0485.2009.00343.x

Weber, M., Lott, C., Fabricius, K.E., 2006. Sedimentation stress in a scleractinian coral exposed to terrestrial and marine sediments with contrasting physical, organic and geochemical properties. J Exp Mar Bio Ecol 336, 18-32. doi:10.1016/j.jembe.2006.04.007

Whinney, J., Jones, R., Duckworth, A., Ridd, P., 2017. Continuous in situ monitoring of sediment deposition in shallow benthic environments. Coral Reefs 36, 521-533. doi:10.1007/s00338-016$1536-7$

Wilson, S.K., Bellwood, D.R., Choat, J.H., Furnas, M.J., 2003. Detritus in the epilithic algal matrix and its use by coral reef fishes. Oceanogr Mar Biol an Annu Rev 41, 279-309.

Wolanski, E., 1994. Physical Oceanographic Processes of the Great Barrier Reef. CRC Press, Florida.

Wolanski, E., Fabricius, K.E., Cooper, T.F., Humphrey, C., 2008. Wet season fine sediment dynamics on the inner shelf of the Great Barrier Reef. Estuar Coast Shelf Sci 77, 755-762. doi:10.1016/j.ecss.2007.10.014

Woolfe, K.J., Larcombe, P., 1999. Terrigenous sedimentation and coral reef growth: A conceptual framework. Mar Geol 155, 331-345. doi:10.1016/S0025-3227(98)00131-5 